\title{
Pengaruh Edible Coating Ekstrak Daun Cincau Hitam Terhadap Umur Simpan Buah Anggur Hitam (Vitis vinivera)
}

\author{
Effect of Edible Coating from Black Grass Jelly Leaf Extract on the Shelf Life \\ of Black Grapes (Vitis vinifera)
}

\author{
La Choviya Hawa*, Musthofa Lutfi, Firli Febbianti \\ Jurusan Keteknikan Pertanian, Fakultas Teknologi Pertanian, Universitas Brawijaya, Jl. Veteran, Malang 65145 \\ *E-mail: la_choviya@ub.ac.id
}

Diterima: 15 Januari 2020; Disetujui: 6 Agustus 2020

\begin{abstract}
ABSTRAK
Buah anggur hitam merupakan buah yang memiliki kandungan air relatif tinggi dan mudah rusak, sehingga tidak dapat bertahan lama jika disimpan dalam keadaan segar. Untuk mengatasi permasalahan ini, upaya yang dapat dilakukan ialah dengan pengaplikasian edible coating yang terbuat dari ekstrak daun cincau hitam. Dalam daun cincau hitam, terkandung senyawa pektin yang merupakan bahan utama untuk membuat edible coating. Tujuan dari penelitian ini ialah menganalisa perubahan mutu buah anggur hitam yang dilapisi dengan edible coating dari ekstrak daun cincau hitam. Serta menentukan umur simpannya dengan menggunakan metode ASLT (Accelerated Shelf Life Testing) melalui pendekatan Arrhenius, yang disimulasikan pada tiga kondisi suhu penyimpanan yaitu $8^{\circ} \mathrm{C} \pm 3^{\circ} \mathrm{C}, 16^{\circ} \mathrm{C} \pm 3^{\circ} \mathrm{C}$, dan $25^{\circ} \mathrm{C} \pm 3^{\circ} \mathrm{C}$. Parameter yang diamati selama proses penyimpanan adalah susut bobot, kadar air, tekstur, total padatan terlarut, vitamin $\mathrm{C}$, dan uji organoleptik (tekstur, warna, aroma, dan rasa). Hasil penelitian menunjukkan bahwa aplikasi edible coating ekstrak daun cincau hitam, mampu mengurangi penyusutan, menghambat turunnya kadar air, dan timbulnya keriput pada permukaan kulit buah, serta mampu mempertahankan kekerasan buah anggur hitam. Buah anggur hitam yang dilapisi dengan edible coating dan disimpan pada suhu $8^{\circ} \mathrm{C}, 16^{\circ} \mathrm{C}$, dan $25^{\circ} \mathrm{C}$ umur simpannya mencapai 26,3 hari, 26 hari, dan 25,3 hari. Sedangkan buah anggur tanpa edible coating yang disimpan pada suhu $8^{\circ} \mathrm{C}, 16^{\circ} \mathrm{C}$, dan $25^{\circ} \mathrm{C}$ umur simpannya mencapai 14,3 hari, 14 hari, dan 13,2 hari.
\end{abstract}

Kata kunci: Anggur; Arrhenius; Edible Coating; Umur Simpan

\begin{abstract}
Black grapes are fruits that have a relatively high water content and are easily damaged, so they cannot last long if they are kept fresh. To overcome this problem, one of the efforts that can be done is by applying edible coating made from black grass jelly leaf extract. In the black grass jelly leaves, it contains pectin compounds which are the main ingredients for making edible coating. The purpose of this research was to analyze the changes in the quality of black grapes coated with edible coating from black grass jelly leaf extract. And to determine the shelf life by using the ASLT (Accelerated Shelf Life Testing) method through the Arrhenius approach, which is simulated in three conditions of storage temperature namely $8^{\circ} \mathrm{C} \pm 3^{\circ} \mathrm{C}, 16^{\circ} \mathrm{C} \pm 3^{\circ} \mathrm{C}$, and $25^{\circ} \mathrm{C} \pm 3^{\circ} \mathrm{C}$. The parameters observed during the storage process were weight loss, moisture content, firmness, total dissolved solids, vitamin $C$, and organoleptic analysis (firmness, colour, aroma, and taste). The results showed that the application of edible coating of black grass jelly leaf extract, was able to reduce shrinkage, inhibits a decrease in water content, inhibits the appearance of wrinkles on the surface of the fruit skin, and was able to maintain the firmness of black grapes. Black grapes are coated with edible coating and stored at $8^{\circ} \mathrm{C}, 16^{\circ} \mathrm{C}$, and $25^{\circ} \mathrm{C}$, the shelf life reaches 26.3 days, 26 days, and 25.3 days. While grapes without edible coating stored at $8^{\circ} \mathrm{C}, 16^{\circ} \mathrm{C}$, and $25^{\circ} \mathrm{C}$ the shelf life reaches 14.3 days, 14 days, and 13.2 days.
\end{abstract}

Keywords: Grapes; Arrhenius; Edible Coating; Shelf Life

\section{PENDAHULUAN}

Anggur merupakan yang kaya vitamin, mineral, karbohidrat dan senyawa fitokimia. Buah anggur tergolong buah dengan kandungan air relatif tinggi yaitu sekitar $70 \%$. Di Indonesia, permintaan konsumsi anggur tertinggi terjadi pada tahun 2004 yang semula sebesar 26 ton menjadi 42 ton (61,54\%). Menurut Coniwanti dkk. (2014), anggur tergolong dalam buah yang rentan mengalami kerusakan, dan tidak bertahan lama jika disimpan dalam kondisi segar. Suhu optimal untuk penyimpanan buah anggur sendiri berkisar $-1^{\circ} \mathrm{C}$ sampai $4^{\circ} \mathrm{C}$ dengan daya simpannya mencapai 4-6 minggu (Sudjatha dan Ni, 2017). Sedangkan jika buah disimpan pada suhu ruang $\left(28^{\circ} \mathrm{C}-31^{\circ} \mathrm{C}\right.$ dengan $\mathrm{RH} 80-85 \%$ ) daya simpannya mencapai 14 hari.

Penanganan pasca panen yang tepat, perlu dilakukan guna meminimalisir kerusakan selama penyimpanan dan memperpanjang umur simpan. Adapun upaya yang dapat dilakukan ialah dengan melakukan modifikasi atmosfer atau dengan penyimpanan produk pada ruang pendingin. Dari segi biaya, penyimpanan dengan menggunakan kedua cara tersebut membutuhkan biaya yang mahal. Salah satu alternatif penyimpanan adalah dengan penambahan edible coating.

Edible coating merupakan lapisan semi permeable yang dapat dikonsumsi dan membentuk barrier untuk mengurangi kelembaban, pertukaran gas, dan migrasi zat 
terlarut (Krochta dkk., 2002). Edible coating dapat berasal dari polisakarida, protein, dan lipid dengan penambahan surfaktan dan peliat (Pascall dan Lin, 2013). Menurut Raghav dkk. (2016), syarat utama dalam pembuatan edible coating ialah tidak berbau, tidak berasa dan tidak mengubah karakteristik dari produk aslinya. Oleh karena itu, bahan baku coating yang sesuai untuk melapisi buah anggur hitam ialah daun cincau hitam.

Daun cincau hitam merupakan sumber hidrokoloid yang tersedia melimpah di alam. Komponen penyusun daun cincau hitam sendiri meliputi karbohidrat, lemak, fosfor, saponin, kalsium, polifenol vitamin A dan B, serta polisakarida pektin yang bermetoksi rendah (Rachmawati, 2010). Menurut Irawan (1997) dalam Murdianto dkk. (2005), gel cincau hitam bersifat tahan terhadap perebusan, dan apabila dikeringkan akan mempunyai sifat yang amat rekat sehingga tidak mudah sobek dan transparan. Edible coating daun cincau hitam ini, berbeda dengan edible coating lainnya yang hanya berfungsi sebagai penahan permeabilitas air dan oksigen saja. Edible coating daun cincau hitam ini juga berkhasiat sebagai antioksidan, antibakteri, antidiabetes, dan antikolesterol (Simamora dkk., 2019).

Menurut Faridah dkk. (2013), untuk menjamin produk pangan masih aman dan layak dikonsumsi oleh konsumen maka diperlukan informasi mengenai umur simpannya. Umur simpan adalah rentang waktu yang dibutuhkan suatu produk untuk mempertahankan mutunya, hingga produk ditolak oleh konsumen (Herawati, 2008). Pada penelitian ini, umur simpan didapatkan dari parameter dengan nilai energi aktivasi terendah. Umur simpan buah anggur edible coating ditentukan dengan menggunakan metode Accelerated Shelf-Life Testing (ASLT) melalui pendekatan Arrhenius. Kelebihan ASLT dibanding metode Extended Storage Studies (ESS) adalah periode pengujian ASLT lebih cepat dengan nilai keakuratan yang relatif tinggi sehingga jumlah biaya yang dikeluarkan relatif kecil. Prinsip utama dari metode ASLT ialah mempercepat laju kerusakan suatu produk dengan cara menyimpan produk di luar suhu normal sehingga laju reaksi kerusakan dapat lebih cepat terjadi (Khamidah, 2010).

Tujuan dari penelitian ini ialah menganalisa perubahan mutu buah anggur hitam yang dilapisi dengan edible coating dari ekstrak daun cincau hitam. Serta menentukan umur simpannya dengan menggunakan metode ASLT melalui pendekatan Arrhenius, yang disimulasikan pada tiga kondisi suhu penyimpanan yaitu $8^{\circ} \pm 3^{\circ} \mathrm{C}, 16 \pm 3^{\circ} \mathrm{C}$, dan $25 \pm 3^{\circ} \mathrm{C}$

\section{METODOLOGI}

\section{Alat dan Bahan}

Pada penelitian ini, peralatan yang digunakan adalah timbangan analitik tipe HWH DJ1002A, hot plate thermo scientific "Cimarec HP 131530-33Q", oven Heraeus tipe T 5050, blender Phillips tipe HR-2102/06, thermometer digital tipe TPM-10, lemari pendingin merk Electrolux, hand dan refractometer $0-32 \%$ brix. Sedangkan bahan yang digunakan ialah buah anggur hitam, daun cincau hitam, tepung tapioka, sorbitol, CMC, ethanol 96\%, dan aquades.

\section{Metode Penelitian}

Dalam penelitian ini, rancangan percobaan yang digunakan ialah Rancangan Acak Lengkap Faktorial dengan menggunakan 2 perlakuan dan 3 kali pengulangan. Perlakuan yang pertama adalah variasi suhu penyimpanan buah anggur yang terdiri dari suhu $8^{\circ} \mathrm{C} \pm 3^{\circ} \mathrm{C}, 16^{\circ} \mathrm{C} \pm 3^{\circ} \mathrm{C}$, dan $25^{\circ} \mathrm{C} \pm 3^{\circ} \mathrm{C}$. Sedangkan perlakuan yang kedua adalah perlakuan pelapisan buah anggur hitam (non coating, coating, dan coating+wrapping). Non coating adalah buah anggur yang tidak diberi perlakuan pelapisan maupun pengemasan dengan plastic wrap. Coating adalah buah anggur yang dilapisi dengan edible coating daun cincau hitam. Wrapping adalah buah anggur yang telah dilapisi dengan edible coating disimpan dalam wadah sterofoam, kemudian dikemas menggunakan plastic wrap. Untuk pendugaan umur simpan buah anggur hitam pada beberapa perlakuan tersebut, dilakukan dengan metode ASLT melalui pendekatan Arrehenius. Parameter yang diuji pada penelitian ini, meliputi susut bobot, kadar air, total padatan terlarut, kekerasan, dan vitamin C. Adapun tahapan dalam penelitian ini ialah:

\section{Pembuatan bubuk ekstrak daun cincau hitam}

Bubuk daun cincau hitam sebanyak 25gram dicampur dengan $600 \mathrm{~mL}$ aquades, lalu dipanaskan selama 1 jam menggunakan hot plate pada suhu $90^{\circ} \mathrm{C}$ $95^{\circ} \mathrm{C}$ yang dilengkapi magnetic stirrer untuk pengadukan. Setelah itu larutan didinginkan selama 30 menit. Selanjutnya larutan disaring dan didapatkan dua fraksi yaitu filtrat dan ampas. Filtrat ditambahkan etanol $96 \%$ menggunakan rasio $1: 1$. Kemudian larutan disaring sehingga didapatkan dua fraksi, yaitu fraksi gel dan cair. Lalu gel dikeringkan dalam oven bersuhu $50^{\circ} \mathrm{C}$ selama 24 jam. Hasil setelah pengovenan berupa lembaranlembaran kering ekstrak cincau hitam. Selanjutnya lembaran ekstrak tersebut dihaluskan dan diayak dengan ayakan 100 mesh (Hendrawan, 2017).

\section{Pembuatan edible coating ekstrak daun cincau} hitam

Larutan edible coating dibuat dengan memanaskan $4 \mathrm{gr}$ tapioka, $200 \mathrm{ml}$ aquades dan sorbitol $1 \% \mathrm{~b} / \mathrm{v}$ pada suhu $75^{\circ} \mathrm{C}-85^{\circ} \mathrm{C}$ selama 20 menit. Kemudian larutan ini dicampur ekstrak cincau hitam dengan konsentrasi 10\% b/b tapioka dan CMC 1\%. Selanjutnya larutan didinginkan hingga suhu $\pm 30^{\circ} \mathrm{C}$ (Hendrawan, 2017).

\section{Proses pelapisan buah anggur hitam}

Larutan edible coating ekstrak daun cincau hitam disiapkan dalam gelas beker. Lalu dilakukan pencelupan pada beberapa biji buah anggur sampai seluruh permukaannya tercelup merata dalam larutan edible coating selama 5 menit. Kemudian buah anggur yang telah dicoating ditiriskan dalam tray yang berlubang dan dikering anginkan menggunakan kipas angin selama 3-5 jam. Proses penirisan dapat dihentikan ketika buah tampak benar-benar kering dan penampilannya menjadi mengkilap. Buah anggur yang telah kering dibagi menjadi 2 bagian, yaitu buah anggur yang diwrapping dan buah anggur yang tidak diwrapping. Selanjutnya buah anggur non coating, coating, dan coating+wrapping masing-masing disimpan pada suhu $8^{\circ} \mathrm{C}, 16^{\circ} \mathrm{C}$, dan $25^{\circ} \mathrm{C}$.

4. Penentuan umur simpan dengan menggunakan metode ASLT melalui pendekatan Arrhenius

a. Pengamatan buah anggur dilakukan pada hari ke-0, 3 , 6, 9, dan 12 dengan parameter pengamatan meliputi susut bobot, kadar air, total padatan terlarut, tekstur dan kandungan vitamin $\mathrm{C}$. Hasil pengamatan pada hari ke-0 digunakan sebagai nilai awal buah anggur sebelum penyimpanan $\left(A_{0}\right)$.

b. Data yang diperoleh dari setiap parameter pengamatan terhadap lama penyimpanan diplotkan dan dihitung persamaan regresi liniernya. Umumnya regresi linier ditentukan dengan menggunakan persamaan $y=a+b x$. Dimana $y=$ perubahan nilai karakteristik buah anggur, $x=$ lama penyimpanan (hari), $a=$ nilai karakteristik awal buah anggur, $b=$ 
laju perubahan nilai karakteristik buah anggur (didapatkan dari slope, nilai $b=$ nilai $k$ ).

c. Dalam menentukan ordo reaksi yang akan digunakan, perlu dibuat grafik ordo nol dan grafik ordo satu. Dimana grafik ordo nol merupakan grafik yang menunjukkan hubungan antara nilai $k$ dengan waktu penyimpanan. Sedangkan grafik ordo satu merupakan grafik yang menunjukkan hubungan antara In $\mathrm{k}$ dengan waktu penyimpanan. Untuk menentukan ordo reaksi yang digunakan, dipilih persamaan yang memiliki nilai $R^{2}$ terbesar dan mendekati 1.

d. Untuk pendekatan Arrhenius, nilai In k dari masingmasing suhu penyimpanan diplotkan terhadap $1 / \mathrm{T}$ $\left(\mathrm{K}^{-1}\right)$ sehingga didapatkan $\ln k_{0}$ dan slope dari persamaan regresi linier $\ln k=\ln k_{0}-\left(\frac{E a}{R}\right)\left(\frac{1}{T}\right)$, dimana $\ln k_{0}=$ intersep, $\frac{E a}{R}=$ slope, $E a=$ energi aktivasi, dan $\mathrm{R}=$ konstanta gas ideal $(1,986$ $\mathrm{kal} / \mathrm{mol}$ ).

e. Pada tahapan sebelumnya, didapatkan nilai $k_{0}$ yang merupakan faktor eksponensial dan nilai $E a$ reaksi perubahan karakteristik buah anggur, kemudian ditentukan model persamaan laju reaksi (k) perubahan karakteristik buah anggur dengan persamaan $k=k_{0} \cdot e^{-E / R T}$.

f. Penentuan parameter yang paling berpengaruh terhadap penurunan nilai karakteristik produk, dilakukan dengan melihat parameter yang memiliki nilai energi aktivasi $(E a)$ terendah.

g. Untuk menentukan umur simpan buah anggur dihitung dengan menggunakan persamaan kinetika reaksi berdasarkan orde reaksinya. Untuk pendugaan umur simpan laju reaksi orde nol digunakan persamaan $t=\left(A_{0}-A_{t}\right) / k$, sedangkan untuk pendugaan umur simpan laju reaksi orde satu digunakan persamaan $t=\ln \left(A_{0}-A_{t}\right) / k$. Dimana $\mathrm{t}$ = umur simpan buah anggur (hari), $A_{0}=$ nilai karakteristik awal buah anggur, $A_{t}=$ nilai karakteristik akhir buah anggur, dan $\mathrm{k}=$ konstanta penurunan mutu buah anggur.

\section{HASIL DAN PEMBAHASAN}

\section{Karakteristik Mutu Awal dan Akhir Buah Anggur Hitam}

Penentuan mutu kritis buah anggur hitam dilakukan berdasarkan uji organoleptik dengan perlakuan non coating, coating, dan coating+wrapping dengan penyimpanan pada suhu $25^{\circ} \mathrm{C}$. Skor penerimaan konsumen pada penelitian ini ditentukan berdasarkan parameter warna, tekstur, aroma dan rasa. Skor penolakan buah anggur selama penyimpanan suhu $25^{\circ} \mathrm{C}$ disajikan pada Tabel 1 .

Tabel 1. Skor penolakan buah anggur selama penyimpanan suhu $25^{\circ} \mathrm{C}$

\begin{tabular}{|c|c|c|c|c|c|c|}
\hline \multirow[t]{2}{*}{ Perlakuan } & \multirow{2}{*}{$\begin{array}{c}\text { Waktu } \\
\text { Penola } \\
\text { kan }\end{array}$} & \multicolumn{4}{|c|}{$\begin{array}{c}\text { Hasil Uji } \\
\text { Organoleptik } \\
\end{array}$} & \multirow{2}{*}{$\begin{array}{c}\% \\
\text { Tolak }\end{array}$} \\
\hline & & 1 & 2 & 3 & 4 & \\
\hline $\begin{array}{l}\text { Non } \\
\text { Coating }\end{array}$ & 12 hari & 3,6 & 3,3 & 3,8 & 4,3 & 60 \\
\hline Coating & 13 hari & 3,5 & 3,3 & 3,7 & 4,5 & 60 \\
\hline $\begin{array}{l}\text { Coating }+ \\
\text { wrapping }\end{array}$ & 14 hari & 3,6 & 3,2 & 3,8 & 4,5 & 60 \\
\hline
\end{tabular}

Keterangan: 1= aroma; 2=rasa; $3=$ tekstur; dan 4= warna

Berdasarkan Tabel 1, dapat diketahui bahwa $\geq 50 \%$ panelis menolak buah anggur dengan perlakuan non coating, coating, dan coating+wrapping setelah penyimpanan hari ke-12, 13, dan 14 dengan suhu penyimpanan $25^{\circ} \mathrm{C}$. Penolakan buah anggur oleh panelis pada perlakuan non coating, coating, dan coating+wrapping dikarenakan rasa buah yang berubah dengan diikuti penurunan tekstur serta kulit buah menjadi keriput dan kusam. Pada penelitian ini, parameter rasa merupakan parameter kritis pada uji organoleptik karena memiliki skor penilaian terkecil dibandingkan parameter lainnya.

Untuk menentukan batas waktu penyimpanan buah selama penelitian berlangsung, dapat digunakan data hasil uji organoleptik dengan waktu penolakan tercepat. Dalam penelitian ini, penolakan tercepat terjadi pada buah dengan perlakuan non coating dengan waktu penolakan terjadi pada hari ke-12. Oleh karena itu, pengamatan mutu awal $\left(A_{0}\right)$ dan mutu akhir $\left(A_{t}\right)$ buah anggur dapat diamati selama 12 hari penyimpanan. Untuk gambar kenamakan buah anggur dengan beberapa perlakuan selama 12 hari penyimpanan pada suhu ruang $\left(25^{\circ} \mathrm{C}\right)$ dapat dilihat pada Gambar 1.

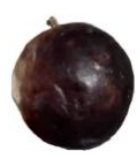

(a)

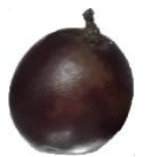

(b)

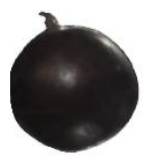

(c)
Gambar 1. Kenampakan buah anggur selama 12 hari penyimpanan pada suhu $25^{\circ} \mathrm{C}$ (a) non coating, (b) coating, (c) coating+wrapping

\section{Susut Bobot}

Susut bobot adalah parameter mutu yang digunakan untuk mengetahui tingkat kesegaran buah. Gambar 2 menunjukkan bahwa susut bobot buah anggur meningkat seiring dengan lamanya penyimpanan. Suhu penyimpanan yang tinggi, juga mempengaruhi besarnya susut bobot yang terjadi. Semakin tinggi suhu maka semakin tinggi susut bobotnya, begitu pula sebaliknya. Pengaruh suhu dalam penelitian ini, dapat dicegah dengan perlakuan pelapisan menggunakan edible coating ekstrak daun cincau hitam.

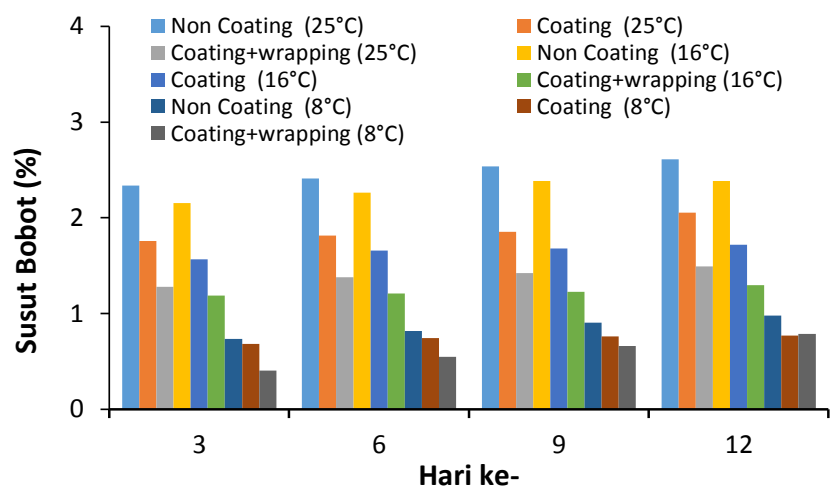

Gambar 2. Grafik hubungan susut bobot buah anggur terhadap lama penyimpanan

Hasil penelitian menunjukkan bahwa buah anggur yang dilapisi dengan edible coating dan disimpan pada suhu $25^{\circ} \mathrm{C}$, mengalami susut bobot yang lebih rendah jika dibandingkan dengan buah anggur non coating dengan suhu penyimpanan yang sama. Namun perlakuan coating + wrapping dan penyimpanan pada suhu rendah merupakan perlakuan terbaik, karena menghasilkan nilai susut bobot terkecil dibandingkan perlakuan lainnya. Aplikasi edible coating pada penelitian ini, mampu mengurangi besarnya penyusutan yang terjadi, karena lapisan edible coating dapat menghambat proses respirasi pada buah anggur, sehingga proses respirasinya masih berjalan lambat. 
Menurut Sohail dkk. (2014), pengaplikasian edible coating pada buah mampu mengurangi terjadinya proses transpirasi dan respirasi, sehingga dapat mengontrol susut bobotnya dan menghambat kemasakan buah. Banyaknya air yang hilang atau menguap dari buah tergantung dari suhu dan kelembaban relatif udara dalam ruang penyimpanan. Semakin tinggi suhu dan semakin rendah kelembaban relatif udara, maka proses transpirasi yang terjadi akan lebih cepat akibatnya buah menjadi layu, lunak dan mengkerut sehingga susut bobotnya bertambah (Hawa, 2005). Untuk pemilihan ordo reaksi parameter susut bobot dapat dilihat pada Tabel 2.

Tabel 2. Orde reaksi parameter susut bobot

\begin{tabular}{cccc}
\hline \multirow{2}{*}{ Perlakuan } & \multirow{2}{*}{ Suhu } & \multicolumn{2}{c}{$\mathbf{R}^{2}$} \\
\cline { 3 - 4 } & & Ordo 0 & Ordo 1 \\
\hline \multirow{2}{*}{ Coating +} & $8^{0} \mathrm{C} \pm 3^{0} \mathrm{C}$ & 0,9977 & 0,9797 \\
wrapping & $16^{\circ} \mathrm{C} \pm 3^{\circ} \mathrm{C}$ & 0,9013 & 0,9081 \\
& $25^{\circ} \mathrm{C} \pm 3^{\circ} \mathrm{C}$ & 0,9778 & 0,972 \\
\hline \multirow{4}{*}{ Coating } & $8^{0} \mathrm{C} \pm 3^{\circ} \mathrm{C}$ & 0,8344 & 0,8258 \\
& $16^{\circ} \mathrm{C} \pm 3^{\circ} \mathrm{C}$ & 0,9183 & 0,9117 \\
& $25^{\circ} \mathrm{C} \pm 3^{\circ} \mathrm{C}$ & 0,8619 & 0,8745 \\
\hline \multirow{3}{*}{ Non Coating } & $8^{0} \mathrm{C} \pm 3^{0} \mathrm{C}$ & 0,9988 & 0,995 \\
& $16^{\circ} \mathrm{C} \pm 3^{\circ} \mathrm{C}$ & 0,8962 & 0,8942 \\
& $25^{\circ} \mathrm{C} \pm 3^{\circ} \mathrm{C}$ & 0,9906 & 0,9906 \\
\hline
\end{tabular}

Dari Tabel 2 dapat diketahui bahwa koefisien korelasi $\left(R^{2}\right)$ orde nol lebih besar dari koefisien korelasi $\left(R^{2}\right)$ orde satu maka laju kenaikan nilai susut bobot mengikuti reaksi orde nol.

\section{Kadar Air}

Kadar air adalah indikator penentu tingkat kesegaran maupun keawetan bahan pangan, karena kadar air berpengaruh terhadap sifat fisik maupun kimia bahan. Gambar 3 menunjukkan bahwa penurunan kadar air buah anggur dipengaruhi oleh suhu dan waktu penyimpanan. Makin tinggi suhu, maka penurunan kadar air yang terjadi makin tinggi pula. Selain itu, adanya perlakuan pelapisan dengan edible coating pada penelitian ini, juga berpengaruh tehadap nilai kadar air yang dihasilkan.

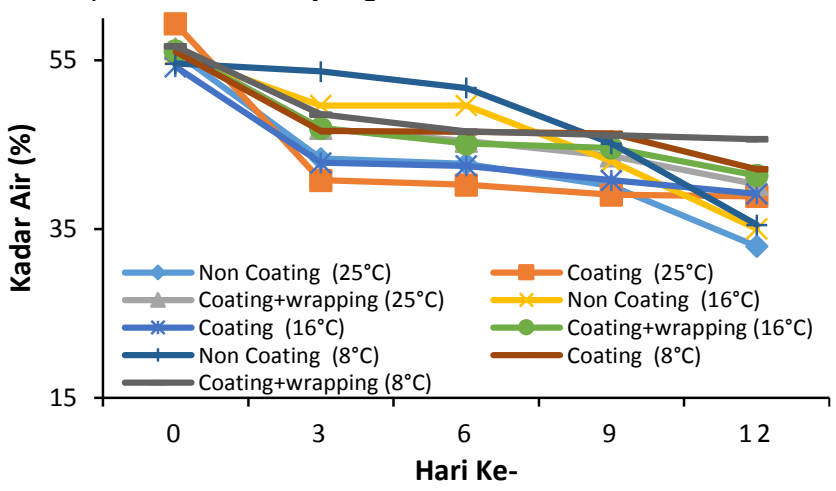

Gambar 3. Grafik hubungan kadar air buah anggur terhadap lama penyimpanan

Hasil penelitian menunjukkan bahwa buah anggur dengan perlakuan coating menghasilkan penurunan kadar air yang rendah dibandingkan perlakuan non coating. Namun perlakuan coating+wrapping merupakan perlakuan terbaik untuk menghambat penurunan kadar air dalam buah. Aplikasi edible coating dalam penelitian ini, dapat mempertahankan uap air dari dalam maupun luar lapisan edible coating.
Penurunan nilai kadar air terjadi karena air dalam buah anggur mengalami penguapan selama proses penyimpan yang diakibatkan oleh suhu dan penyimpanan. Menurut Djaeni dkk. (2012), besarnya suhu maupun kecepatan udara yang tinggi mampu meningkatkan transpirasi. Peningkatan transpirasi ini disebabkan oleh perbedaan tekanan uap cairan. Untuk pemilihan ordo reaksi parameter kadar air dapat dilihat pada Tabel 3.

Tabel 3. Orde reaksi parameter kadar air

\begin{tabular}{cccc}
\hline \multirow{2}{*}{ Perlakuan } & \multirow{2}{*}{ Suhu } & \multicolumn{2}{c}{$\mathbf{R}^{2}$} \\
\cline { 3 - 4 } & & Ordo 0 & Ordo 1 \\
\hline \multirow{2}{*}{ Coating +} & $8^{0} \mathrm{C} \pm 3^{0} \mathrm{C}$ & 0,9679 & 0,977 \\
wrapping & $16^{\circ} \mathrm{C} \pm 3^{\circ} \mathrm{C}$ & 0,9633 & 0,9771 \\
& $25^{\circ} \mathrm{C} \pm 3^{\circ} \mathrm{C}$ & 0,9581 & 0,9733 \\
\hline \multirow{4}{*}{ Coating } & $8^{\circ} \mathrm{C} \pm 3^{\circ} \mathrm{C}$ & 0,9738 & 0,9767 \\
& $16^{\circ} \mathrm{C} \pm 3^{\circ} \mathrm{C}$ & 0,9797 & 0,9802 \\
& $25^{\circ} \mathrm{C} \pm 3^{\circ} \mathrm{C}$ & 0,9517 & 0,9501 \\
\hline \multirow{3}{*}{ Non Coating } & $8^{\circ} \mathrm{C} \pm 3^{\circ} \mathrm{C}$ & 0,9178 & 0,887 \\
& $16^{\circ} \mathrm{C} \pm 3^{\circ} \mathrm{C}$ & 0,9277 & 0,9035 \\
& $25^{\circ} \mathrm{C} \pm 3^{\circ} \mathrm{C}$ & 0,9682 & 0,9726 \\
\hline
\end{tabular}

Dari Tabel 3, dapat diketahui bahwa pada perlakuan coating+wrapping dan coating nilai $\mathrm{R}^{2}$ orde satu lebih besar dari $\mathrm{R}^{2}$ orde nol maka laju penurunan nilai kadar air mengikuti reaksi orde satu. Sedangkan pada perlakuan non coating, nilai $\mathrm{R}^{2}$ orde nol lebih besar dari ordo satu maka laju penurunan nilai kadar air mengikuti reaksi orde nol.

\section{Total Padatan Terlarut (TPT)}

Nilai TPT dinyatakan dalam skala \%Brix. \%Brix merupakan jumlah sukrosa yang terdapat pada buah. Gambar 4. menunjukkan bahwa nilai TPT, mengalami peningkatan selama penyimpanan. Makin kecil suhu penyimpanan, maka kenaikan nilai TPT yang terjadi akan makin besar. Pada penelitian ini, perubahan nilai TPT yang terjadi akibat perlakuan pelapisan pada buah anggur, perubahannya relatif kecil terutama pada anggur coating + wrapping dan anggur coating. Pengaplikasian plastic wrap sebagai bahan pengemas, tidak begitu berpengaruh terhadap nilai TPT yang dihasilkan.

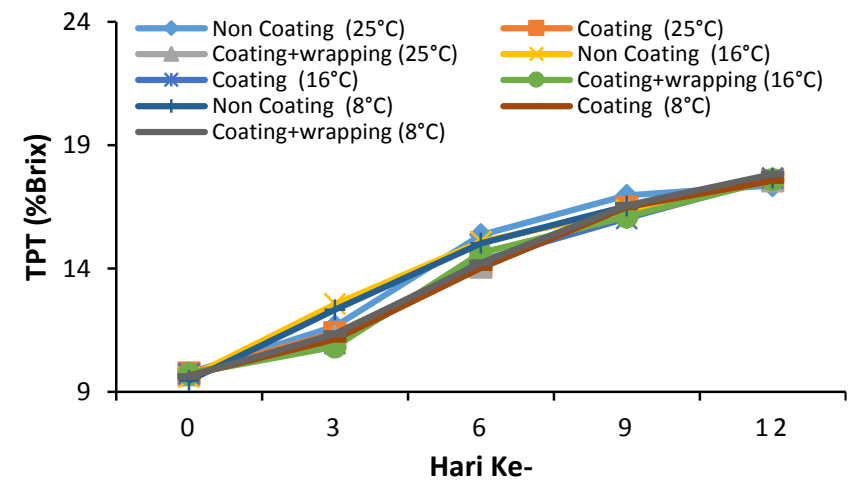

Gambar 4. Grafik hubungan TPT buah anggur terhadap lama penyimpanan

Peningkatan nilai TPT yang terjadi pada penelitian ini bertentangan dengan pendapat Winarno dan Wirakartakusumah (1981), yang menyatakan bahwa buah non klimaterik perubahan kadar gulanya cenderung tetap atau perubahan yang terjadi relatif kecil. Peningkatan nilai TPT pada penelitian ini, diduga dipengaruhi oleh jenis buah anggur yang digunakan dan umur pemanenan buah yang kurang tepat. Menurut Budiyati dkk. (2015), setiap jenis buah anggur memiliki nilai TPT yang berbeda-beda. Umur 
pemanenan buah anggur yang tidak sesuai mengakibatkan nilai TPT yang dihasilkan rendah, sebab rasa buahnya masih masam. Hal ini sesuai dengan literatur Nyoman dkk. (2015), yang menyatakan buah non klimaterik, contohnya anggur jika dipanen sebelum waktunya rasanya masih masam. Untuk pemilihan ordo reaksi parameter TPT dapat dilihat pada Tabel 4.

Tabel 4. Ordo reaksi parameter TPT

\begin{tabular}{cccc}
\hline \multirow{2}{*}{ Perlakuan } & \multirow{2}{*}{ Suhu } & \multicolumn{2}{c}{$\mathbf{R}^{2}$} \\
\cline { 3 - 4 } Coating + & & Ordo 0 & Ordo 1 \\
wrapping & $8^{0} \mathrm{C} \pm 3^{0} \mathrm{C}$ & 0,9861 & 0,9743 \\
& $16^{\circ} \mathrm{C} \pm 3^{\circ} \mathrm{C}$ & 0,9637 & 0,9496 \\
& $25^{\circ} \mathrm{C} \pm 3^{\circ} \mathrm{C}$ & 0,9841 & 0,9742 \\
\hline \multirow{3}{*}{ Coating } & $8^{0} \mathrm{C} \pm 3^{\circ} \mathrm{C}$ & 0,9798 & 0,9711 \\
& $16^{\circ} \mathrm{C} \pm 3^{\circ} \mathrm{C}$ & 0,9787 & 0,9673 \\
& $25^{\circ} \mathrm{C} \pm 3^{\circ} \mathrm{C}$ & 0,9845 & 0,9748 \\
\hline \multirow{3}{*}{ Non Coating } & $8^{0} \mathrm{C} \pm 3^{\circ} \mathrm{C}$ & 0,9635 & 0,9291 \\
& $16^{\circ} \mathrm{C} \pm 3^{\circ} \mathrm{C}$ & 0,9613 & 0,9247 \\
& $25^{\circ} \mathrm{C} \pm 3^{\circ} \mathrm{C}$ & 0,9316 & 0,9142 \\
\hline
\end{tabular}

Dari Tabel 4 dapat diketahui bahwa koefisien korelasi $\left(R^{2}\right)$ orde nol lebih besar dari koefisien korelasi $\left(R^{2}\right)$ orde satu maka laju kenaikan nilai TPT mengikuti reaksi orde nol.

\section{Kekerasan}

Nilai kekerasan produk adalah parameter utama dalam proses pengawetan suatu produk pangan, terutama untuk produk yang menggunakan edible coating. Hal ini disebabkan, nilai kekerasan dapat digunakan sebagai indikator untuk mengetahui efektivitas coating yang diberikan pada produk tersebut. Gambar 5 menunjukkan bahwa nilai kekerasan buah terus mengalami penurunan selama penyimpanan. Kekerasan merupakan faktor penting dalam mempengaruhi kualitas buah anggur hitam selama penyimpanan. Pada penelitian ini, buah anggur dengan perlakuan coating + wrapping mengalami penurunan terendah dibandingkan buah anggur dengan perlakuan coating dan non coating. Hal ini menunjukkan bahwa perlakuan coating + wrapping dapat melindungi buah dari penurunan kekerasan.

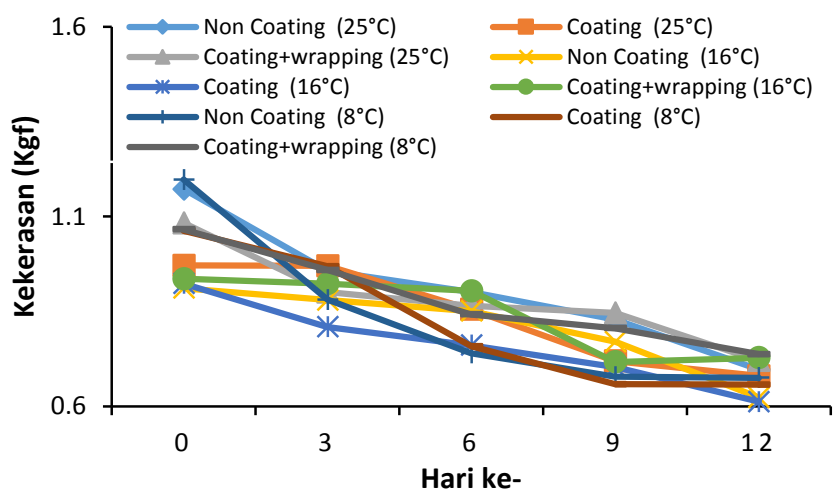

Gambar 5. Grafik hubungan kekerasan buah anggur terhadap lama penyimpanan

Dalam penelitian ini, aplikasi edible coating ekstrak daun cincau hitam mampu menghambat respirasi dan transpirasi, sehingga kekerasan buah anggur tetap terjaga. Menurut Apandi (1984), perubahan tekstur buah dari keras menjadi lunak merupakan akibat dari proses kelayuan (keriput) karena respirasi dan transpirasi. Untuk pemilihan ordo reaksi parameter kekerasan dapat dilihat pada Tabel 5 .

Tabel 5. Ordo reaksi parameter kekerasan

\begin{tabular}{cccc}
\hline \multirow{2}{*}{ Perlakuan } & \multirow{2}{*}{ Suhu } & \multicolumn{2}{c}{$\mathbf{R}^{2}$} \\
\cline { 3 - 4 } & & Ordo 0 & Ordo 1 \\
\hline \multirow{2}{*}{ Coating +} & $8^{0} \mathrm{C} \pm 3^{0} \mathrm{C}$ & 0,9646 & 0,8631 \\
wrapping & $16^{\circ} \mathrm{C} \pm 3^{\circ} \mathrm{C}$ & 0,8083 & 0,8724 \\
& $25^{\circ} \mathrm{C} \pm 3^{\circ} \mathrm{C}$ & 0,8893 & 0,8295 \\
\hline \multirow{3}{*}{ Coating } & $8^{\circ} \mathrm{C} \pm 3^{\circ} \mathrm{C}$ & 0,9145 & 0,7892 \\
& $16^{\circ} \mathrm{C} \pm 3^{\circ} \mathrm{C}$ & 0,9794 & 0,981 \\
& $25^{\circ} \mathrm{C} \pm 3^{\circ} \mathrm{C}$ & 0,9311 & 0,9149 \\
\hline \multirow{3}{*}{ Non Coating } & $8^{\circ} \mathrm{C} \pm 3^{0} \mathrm{C}$ & 0,8081 & 0,8522 \\
& $16^{\circ} \mathrm{C} \pm 3^{\circ} \mathrm{C}$ & 0,8828 & 0,8514 \\
& $25^{\circ} \mathrm{C} \pm 3^{\circ} \mathrm{C}$ & 0,9464 & 0,962 \\
\hline
\end{tabular}

Dari Tabel 5 dapat diketahui bahwa pada perlakuan coating+wrapping nilai $\mathrm{R}^{2}$ orde satu lebih besar dari $\mathrm{R}^{2}$ orde nol maka laju penurunan nilai kekerasan mengikuti reaksi orde satu. Sedangkan pada perlakuan coating dan non coating, nilai $\mathrm{R}^{2}$ orde nol lebih besar dari ordo satu maka laju penurunan nilai kekerasan mengikuti reaksi orde nol.

Penurunan kekerasan juga terdeteksi pada buah lain seperti sawo yang disimpan pada kondisi hipobarik (Hawa, 2006) berkaitan dengan senyawa pektin. Di dalam dinding sel dan lamela tengah, pektin berfungsi sebagai bahan perekat. Salah satu fungsi pektin adalah menjaga ketegaran buah dan dengan adanya perubahan pektin maka ketegaran buah akan berkurang.

\section{Vitamin C}

Vitamin $\mathrm{C}$ atau asam askorbat mempunyai banyak manfaat bagi tubuh. Asam askorbat sendiri merupakan bahan yang memiliki kemampuan mereduksi yang sangat kuat dan dapat bertindak sebagai antioksidan. Gambar 6 . menunjukkan bahwa vitamin $\mathrm{C}$ buah anggur mengalami penurunan selama penyimpanan. Tingginya suhu penyimpanan yang digunakan dan pengaplikasian edible coating juga mempengaruhi besarnya vitamin $\mathrm{C}$. Penurunan vitamin $\mathrm{C}$ pada perlakuan coating tidak terlalu besar dibandingkan dengan perlakuan non coating, karena lapisan edible coating mampu menghambat masuknya oksigen dalam buah.

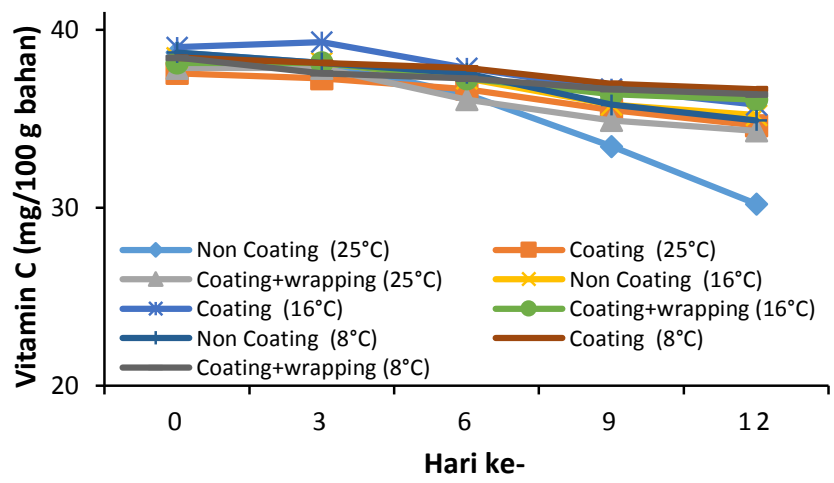

Gambar 6. Grafik hubungan vitamin C buah anggur terhadap lama penyimpanan

Pada penelitian ini, penurunan vitamin $\mathrm{C}$ yang terjadi pada buah anggur diduga dipengaruhi oleh beberapa faktor, yaitu suhu penyimpanan, tingkat kematangan buah, dan sifat dari vitamin $C$ sendiri yang mudah teroksidasi apabila disimpan dalam waktu yang lama. Menurut Astria dkk. (2018), penurunan vitamin C pada buah anggur hijau 
disebabkan oleh sifat vitamin C yang mudah teroksidasi. Oleh karena itu, vitamin $\mathrm{C}$ akan mengalami penurunan jika penyimpanan berlangsung lama.

Sedangkan menurut Hernandes dkk. (2002) dalam Imaduddin dkk. (2017), kadar vitamin C akan mengalami penurunan seiring dengan kenaikan tingkat kematangan buah. Tingginya tingkat kematangan buah mengakibatkan asam-asam organic seperti asam askorbat diubah menjadi gula-gula sederhana. Untuk pemilihan ordo reaksi parameter vitamin $\mathrm{C}$ dapat dilihat pada Tabel 6.

Tabel 6. Ordo reaksi parameter vitamin C

\begin{tabular}{cccc}
\hline \multirow{2}{*}{ Perlakuan } & \multirow{2}{*}{ Suhu } & \multicolumn{2}{c}{$\mathbf{R}^{2}$} \\
\cline { 2 - 4 } & & Ordo 0 & Ordo 1 \\
\hline \multirow{2}{*}{ Coating +} & $8^{0} \mathrm{C} \pm 3^{0} \mathrm{C}$ & 0,9634 & 0,966 \\
wrapping & $16^{\circ} \mathrm{C} \pm 3^{\circ} \mathrm{C}$ & 0,9346 & 0,9349 \\
& $25^{\circ} \mathrm{C} \pm 3^{\circ} \mathrm{C}$ & 0,9383 & 0,9401 \\
\hline \multirow{5}{*}{ Coating } & $8^{0} \mathrm{C} \pm 3^{0} \mathrm{C}$ & 0,9552 & 0,954 \\
& $16^{\circ} \mathrm{C} \pm 3^{\circ} \mathrm{C}$ & 0,9134 & 0,9145 \\
& $25^{\circ} \mathrm{C} \pm 3^{\circ} \mathrm{C}$ & 0,9548 & 0,9517 \\
\hline \multirow{5}{*}{ Non Coating } & $8^{0} \mathrm{C} \pm 3^{0} \mathrm{C}$ & 0,957 & 0,9537 \\
& $16^{\circ} \mathrm{C} \pm 3^{\circ} \mathrm{C}$ & 0,9575 & 0,9557 \\
& $25^{\circ} \mathrm{C} \pm 3^{\circ} \mathrm{C}$ & 0,9453 & 0,9474 \\
\hline \multirow{2}{*}{}
\end{tabular}

Dari Tabel 6 dapat diketahui bahwa pada perlakuan coating+wrapping nilai $\mathrm{R}^{2}$ orde satu lebih besar dari $\mathrm{R}^{2}$ orde nol maka laju penurunan nilai vitamin $C$ mengikuti reaksi orde satu. Sedangkan pada perlakuan coating dan non coating, nilai $\mathrm{R}^{2}$ orde nol lebih besar dari ordo satu maka laju penurunan nilai vitamin $\mathrm{C}$ mengikuti reaksi orde nol.

\section{Pendugaan Umur Simpan}

Umur simpan merupakan rentang waktu penyimpanan produk, hingga produk tersebut mengalami penolakan oleh konsumen. Untuk pendugaan umur simpan buah anggur dapat ditentukan berdasarkan parameter yang memiliki nilai energi aktivasi (Ea) terkecil. Energi aktivasi yang rendah mengakibatkan reaksi kerusakan berjalan cepat sehingga nilai penurunan mutu produk akan semakin besar dan umur simpannya semakin singkat. Berikut disajikan persamaan persamaan Arrhenius dan energi aktivasi dari setiap parameter pada Tabel 7.

Berdasarkan Tabel 7, dapat diketahui bahwa parameter total padatan terlarut merupakan parameter kunci karena menghasilkan energi aktivasi terendah. Sedangkan hasil perhitungan umur simpan buah anggur coating+wrapping, coating, dan non coating pada berbagai suhu penyimpanan dapat dilihat pada Tabel 8.

Tabel 7. Persamaan Arrhenius dan energi aktivasi setiap parameter

\begin{tabular}{lllc}
\hline \multirow{2}{*}{ Parameter } & \multicolumn{1}{c}{ Perlakuan } & Persamaan Arrhenius & Ea (kal/mol) \\
\hline \multirow{3}{*}{ Susut Bobot } & Coating+wrapping & $y=-2660,9 x+6,7102$ & 5284,55 \\
& Coating & $y=-4526,5 x+13,338$ & 8989,63 \\
& Non coating & $y=-4687,7 x+14,17$ & 9309,77 \\
\hline \multirow{3}{*}{ Kadar Air } & Coating+wrapping & $y=-1990,6 x+3,1073$ & 3953,33 \\
& Coating & $y=-2736 x+5,9214$ & 5434,29 \\
\hline \multirow{3}{*}{ TPT } & Non coating & $y=-649,08 x+2,7429$ & 1289,07 \\
& Coating+wrapping & $y=172,38 x-0,9458$ & 342,347 \\
Kekerasan & Coating & $y=119,76 x-0,7748$ & 237,843 \\
& Non coating & $y=24,086 x-0,4718$ & 47,8348 \\
\hline \multirow{3}{*}{ Vitamin C } & Coating+wrapping & $y=188,7 x-4,366$ & 374,758 \\
& Coating & $y=1483,2 x-8,6605$ & 2945,63 \\
& Non coating & $y=858,59 x-6,2389$ & 1705,16 \\
\hline
\end{tabular}

Tabel 8. Hasil perhitungan umur simpan buah anggur hitam pada berbagai suhu berdasarkan parameter TPT

\begin{tabular}{|c|c|c|c|c|}
\hline \multirow{2}{*}{ Perlakuan } & \multicolumn{2}{|c|}{ Suhu } & \multirow{2}{*}{ Nilai $\mathbf{k}$} & \multirow{2}{*}{ Umur Simpan (hari) } \\
\hline & ${ }^{\circ} \mathrm{C}$ & $\mathbf{K}$ & & \\
\hline \multirow{3}{*}{ Coating + wrapping } & 8 & 281 & 0,210241 & 39 \\
\hline & 16 & 289 & 0,21391 & 36,7 \\
\hline & 25 & 298 & 0,217621 & 36,1 \\
\hline \multirow{3}{*}{ Coating } & 8 & 281 & 0,3008631 & 26,3 \\
\hline & 16 & 289 & 0,3044647 & 26 \\
\hline & 25 & 298 & 0,3081403 & 25,3 \\
\hline \multirow{3}{*}{ Non Coating } & 8 & 281 & 0,5726388 & 14,3 \\
\hline & 16 & 289 & 0,5740148 & 14,1 \\
\hline & 25 & 298 & 0,5753942 & 13,2 \\
\hline
\end{tabular}




\section{KESIMPULAN}

Pada uji organoleptic, buah anggur dengan perlakuan non coating mengalami penolakan oleh $>50 \%$ panelis pada hari ke-12. Hasil dari pengamatan uji organoleptik, menunjukkan bahwa parameter kritis yang mempengaruhi mutu dari buah anggur ialah rasa. Pendugaan umur simpan buah anggur dapat ditentukan berdasarkan parameter dengan nilai energi aktivasi (Ea) terkecil. Parameter kritis yang dijadikan dasar untuk menentukan umur simpan pada penelitian ini ialah parameter total padatan terlarut. Umur simpan buah anggur coating yang disimpan pada suhu $8^{\circ} \mathrm{C}$, $16^{\circ} \mathrm{C}$, dan $25^{\circ} \mathrm{C}$ lama penyimpanannya berturut-turut selama 26,3 hari, 26 hari, dan 25,3 hari.

\section{DAFTAR PUSTAKA}

Apandi, M. 1984. Teknologi Buah dan Sayur. Bandung: Alumni

Astria, L.Y., B. Yusuf, dan Alimuddin. 2018. Analisa Kadar Vitamin C pada Buah Anggur Hijau dengan Variasi Lama Penyimpanan Pasca Panen. Jurnal Atomik, Vol. 3(2): $68-72$

Budiyati, E., Leni, dan Apriyanti. 2015. Bertanam Anggur di Pekarangan. Jakarta: Agriflo

Coniwanti, P., D. Pertiwi, dan D. M. Pratiwi. 2014. Pengaruh Peningkatan Konsentrasi Gliserol dan VCO (Virgin Coconut Oil) Terhadap Karakteristik Edible Film dari Tepung Aren. Jurnal Teknik Kimia No. 2, Vol. 20, April 2014

Djaeni, M., A. Prasetyaningrum., dan A. Mahayana. 2012. Pengeringan Karaginan dari Rumput Laut Eucheuma Cottonii pada Spray Dryer Menggunakan Udara yang Didehumidifikasi dengan Zeolit Alam Tinjauan: Kualitas Produk dan Efisiensi Energi. Momentum Volume 8 (2): 28- 34

Faridah, D.N., S. Yasni, A. Suswantinah, dan G.W. Aryani. 2013. Pendugaan Umur Simpan dengan Metode ASLT pada Produk Bandrek Instan dan Sirup Buah Pala (Myristica feagrans). Jurnal IImu Pertanian Indonesia 18(3): 144-153

Hawa, L., C. 2005. Kajian Susut Berat dan Pengembangan Model Laju Respirasi Buah sawo (Achras sapota L.) dalam Penyimpanan Hipobarik. Jurnal Teknologi Pertanian Vol. 6 No.2. $101-111$.

Hawa, L., C. 2006. Pengembangan Model Tekstur dan Umur Simpan Buah Sawo (Achras sapota L.) dengan Variasi Suhu dan Tekanan pada Penyimpanan Hipobarik. Jurnal Teknologi Pertanian Vol. 7 No.1. 10 $-19$.

Hendrawan, Y., S.H. Sumarlan, dan N.A. Ilham. 2017. Pengaruh Konsentrasi Ekstrak Cincau Hijau (Premna Oblongifolia L.) Sebagai Edible Coating dan Lama Pencelupan Terhadap Kualitas Stroberi (Fragaria Sp.). Jurnal Keteknikan Pertanian Tropis dan Biosistem Vol. 5 No. 1, Februari 2017, 35-48

Herawati, H. 2008. Penentuan Umur Simpan pada Produk Pangan. Jurnal Litbang Pertanian vol. 27 No. 4

Imaduddin, A.H., W.H. Susanto, dan N. Wijayanti. 2017. Pengaruh Tingkat Kematangan Buah Belimbing (Averrhoa carambola L.) dan Proporsi Penambahan Gula Terhadap Karakteristik Fisiokimia dan Organoleptik Lempok Belimbing. Jurnal Pangan dan Agroindustri Vol. 5 No. 2: 45-57, April 2017

Khamidah, A. 2010. Aplikasi Metode ASLT dalam Produk Pangan. Malang: Balai Pengkajian Teknologi Pertanian Jawa Timur

Krochta, J.M., E.A. Baldwin, dan M. Nisperos-Carriedo. 2002. Edible Coating and Films to Improve Food Quality. Boca Raton: CPR Press
Murdianto, W., D.W. Marseno, dan Haryadi. 2005. Sifat Fisik dan Mekanik Edible Film dari Ekstrak Daun Janggelan (Mesona palustris BI). AGROSAINS, 18 (3), Juli 2005

Nyoman, G.A.I, N.N.A. Mayadewi, I.M. Sukewijaya, N.L.M Pradnyawathi, dan R. Dwiyani. 2015. Perbaikan Kualitas Buah Anggur Bali (Vitis Vinifera L.) Var. Alphonso Lavallee) Melalui Aplikasi GA3 Sebelum Bunga Mekar. AGROTROP, 5 (1): 37 - 42 (2015)

Pascall \& S.J. Lin. 2013. The Application of Edible Polymeric Film and Coating in the Food Industry. J. of Food Proc. And Tech., 4, e116

Rachmawati, M. 2010. Kajian Sifat Kimia Salak Pondoh (Salacca edulis) dengan Pelapisan Khitosan selama Penyimpanan untuk Memprediksi Masa Simpannya. Jurnal Teknologi Pertanian. 6(1): 20-24

Raghav, P.K., N. Agarwal, dan M. Saini. 2016. Edible Coating of Fruits and Vegetable: A Review. International Journal of Scientific Research and Modern Education (IJSRME). ISSN (Online): 24555630

Simamora, E., E. Pandia, E. Elfrida. 2019. Ekstrak Daun Cincau Hitam (Melasthima palustris) Sebagai Bahan Alami dalam Meningkatkan Mutu dan Masa Simpan pada Buah Tomat. Jurnal Jeumpa, Vol. 6 No.1

Sohail, M., S.R. Afridi, R.U. Khan, F. Ullah, dan B. Mehreen. 2014. Combined Effect of Edible Coating and Packaging Materials on Post Havest Storage Life of Plum Fruits. ARPN Journal of Agricultural and Biological Science. Vol. 9(4): 134-138

Sudjatha dan N.W. Wisaniyata. 2017. Fisiologi dan Teknologi Pascapanen (Buah dan Sayuran). Denpasar: Udayana University Press

Winarno, F.G. dan K. Wirakartakusumah. 1981. Fisiologi Lepas Panen. Jakarta: Sastra Hudaya. 
TEKNOTAN, Vol. 14, No. 1, Agustus 2020

Halaman ini dikosongkan 